Pobrane z czasopisma Annales I - Philosophy and Sociology http://philosophia.annales.umcs.pl Data: 26/04/2023 11:41:36

DOI: $10.17951 / \mathrm{i} .2018 .43 .2 .55-71$

A N N A L E S

UNIVERSITATIS MARIAE CURIE-SKŁODOWSKA

LUBLIN - POLONIA

VOL. XLIII, 2

SECTIO I

2018

\author{
KRZYSZTOF ROJEK \\ ORCID: 0000-0003-1831-3956 \\ Uniwersytet Marii Curie-Skłodowskiej w Lublinie
}

\title{
Filozofia wolności Barucha Spinozy \\ w kontekście interpretacji kompatybilistycznej
}

The Philosophy of Baruch Spinoza's Freedom

in the Context of a Compatibilistic Interpretation

\section{WPROWADZENIE}

Celem artykułu jest dokonanie krytycznej analizy tez B. Spinozy na temat ludzkiej wolności w kontekście założeń postawy kompatybilistycznej. W artykule będę starał się wskazywać jedynie elementy łączące filozofię wolności Spinozy z kompatybilizmem. Wykazywać będę również, z jakich względów utożsamianie filozofii wolności Spinozy ze współczesnym kompatybilizmem może wydawać się dyskusyjne ${ }^{1}$.

$\mathrm{Za}$ dokonaniem zestawienia stanowiska kompatybilistycznego z siedemnastowieczną koncepcją wolności Spinozy przemawia co najmniej kilka zasadniczych powodów. Po pierwsze, kompatybilizm i filozofia Spinozy nie stanowią częstego przedmiotu analizy porównawczej (spośród nowożytnych stanowisk znacznie częściej jako kompatybilistyczne przedstawia się stanowisko T. Hobbesa bądź D. Hume’a). Po drugie, mimo oczywistych różnic zakresowych oba stanowiska uzupełniają się wzajemnie: zarówno kompatybilizm, jak i filozofia wolności Spinozy cechują się nieklasyczną interpretacją wolności, definiując ją nie jako liberum arbitrium voluntatis, lecz jako władzę podmiotu polegającą na samokontroli i samodeterminacji własnych działań. Takie stanowisko spotyka się ze stanowczą krytyką zwolenników libertariańskiej wolności. Zasadności istnienia tej ostatniej nie mogą przyjąć z kolei ani kompatybiliści, ani Spinoza.

1 Por. J. Newman, The Compatibilist Interpretation of Spinoza, "The Personalist" 1974, Vol. 55(4), s. 360, 362. 
Pobrane z czasopisma Annales I - Philosophy and Sociology http://philosophia.annales.umcs.pl Data: 26/04/2023 11:41:36

Ramy tego sporu rozwijam na przestrzeni całego artykułu. Trzeci powód łączy się z trwającym od dziesięcioleci filozoficznym powrotem do problematyki wolności woli i zasadności jej istnienia. Ze względu na wieloznaczność pojęcia wolności trwający renesans na wolność nierzadko wykracza daleko poza stricte filozoficzne ramy problemu. Interdyscyplinarne debaty wokół istnienia i znaczenia wolnej woli niezmiennie dotyczą jednak wciąż nierozwiązanego klasycznego problemu filozoficznego: istnienie wolnej woli a powszechność determinizmu. Współczesne ujęcia problemu nierzadko wykraczają poza klasyczne filozoficzne próby rozwiązania klasycznego problemu. Rozbieżność między klasycznymi i dzisiejszymi próbami rozwiązań prowokuje do zadania pytania, na ile analiza lub reinterpretacja klasycznych stanowisk posiada potencjał do wpłynięcia na współczesny kształt debaty wokół wolnej woli oraz idei wolności².

Ostatnim, mniej zasadniczym, powodem powstania tekstu jest możliwość sformułowania komentarza do publikacji bezpośrednio powiązanych z analizą Spinozjańskiej wolności, uwzględniającego także jej interpretację kompatybilistyczną. W pracy, oprócz przekładów tekstów Spinozy, korzystam z aktualnych polskojęzycznych oraz anglojęzycznych opracowań dotyczących omawianego problemu ${ }^{3}$. Zanim ukażę elementy filozofii wolności Spinozy pod kątem ich zbieżności z kompatybilizmem, przejdę do krótkiej charakterystyki obu stanowisk.

\section{KOMPATYBILIZM}

Kompatybilizm (zwany też słabym determinizmem) nie posiada przypisanego określonego reprezentanta, posiadającego wyłączność na argumentację za tym filozoficznym stanowiskiem. Kompatybilizm stanowi jedną z czterech generalnych możliwości filozoficznego ustosunkowania się do problemu istnienia wolnej woli w kontekście determinizmu. Obok libertarian jedynie kompatybiliści bronią zasadności

2 „Uważam, że filozofia moralna i polityczna może obecnie wyciągnąć niezwykle ważną lekcję z całkowicie dosłownego, bezstronnego i życzliwego namysłu nad Spinozjańską ideą wolności. Niewykluczone, że jego koncepcja wolności jest mimo wszystko trafna, a my znajdujemy się dziś w lepszym położeniu niż nasi przodkowie, aby odkryć jej prawdziwe znaczenie" - S. Hampshire, Spinoza and the Idea of Freedom, [w:] M. Grene (ed.), Spinoza: A Collection of Critical Essays, New York 1973, s. 297, cyt. za: P. Gut, Spinozjańska koncepcja wolności jako działania rozumnego, zgodnego z natura i cnotliwego, „Roczniki Filozoficzne” 2010, nr 1, s. 51.

3 W kontekście niniejszych rozważań wśród publikacji w języku polskim szczególnie inspirujący okazał się artykuł P. Guta. W literaturze anglojęzycznej kwestia ta została podjęta m.in. przez M.J. Kisnera, J. Newmana, S. Hampshire oraz w różnych publikacjach poświęconych filozofii wolności Spinozy. Zob. P. Gut, Spinozjańska koncepcja wolności..., s. 51-70; S. Hampshire, op. cit., s. 297317; M.J. Kisner, Spinoza on Human Freedom. Reason, Autonomy and the Good Life, Cambridge 2011; J. Newman, The Compatibilist Interpretation of Spinoza, "The Personalist" 1974, Vol. 55(4), s. $360-368$. 
Pobrane z czasopisma Annales I - Philosophy and Sociology http://philosophia.annales.umcs.pl Data: 26/04/2023 11:41:36

Filozofia wolności Barucha Spinozy w kontekście interpretacji kompatybilistycznej

istnienia wolnej woli w kontekście determinizmu, różnią ich jednak znacząco poglądy na temat determinizmu. Libertarianie reprezentują wobec wolnej woli stanowisko inkompatybilistyczne. Przyjmując je, opowiadają się za wzajemnym wykluczaniem się możliwości współistnienia wolnej woli i determinizmu, co odpowiada klasycznemu rozumieniu kategorii liberum arbitrium voluntatis. Kompatybiliści dążą zaś do uzasadnienia istnienia wolnej woli niejako mimo powszechności determinizmu przyczynowego ${ }^{4}$. Dostrzegają często zagrożenia ze strony determinizmu, bronią jednak zasadności istnienia wolności woli, opierając swoje wywody na zagrożeniu ze strony przyjęcia stanowiska indeterministycznego. Jak pisze J. Newman:

Istnieją dwie wersje teorii kompatybilistycznych: silna oraz słaba. Zwolennicy tej pierwszej uznają istnienie determinizmu przyczynowego jako niezbędnego warunku przypisywania moralnej odpowiedzialności; zwolennicy tej ostatniej teorii postrzegają determinizm przyczynowy po prostu jako niezwiązany z kwestią moralnej odpowiedzialności. Zwolennicy obu wersji teorii ostatecznie określają moralną odpowiedzialność na podstawie świadomych przyczyn, intencji lub motywów podmiotu, nie zaś na podstawie przyczyn fizycznych ${ }^{5}$.

Kompatybiliści najczęściej formułują zarzut wobec libertarian, według którego wszelka nieokreśloność (stanowiąca warunek wyłomu z łańcucha przyczynowego, niezbędnego dla istnienia wolności w rozumieniu wolności libertariańskiej) prowadzi do losowości. Ta ostatnia, stanowiąc przejaw zewnętrznej determinacji, musi zaś wykluczać wolność. Libertarianie starają się z kolei bronić wolnej woli przed zarzutem losowości. Bezwzględnym warunkiem przyjęcia ich postawy jest jednak negacja tezy o powszechności determinizmu przyczynowego.

Powyższy zarys różnic stanowi podstawę i często bezpośredni przedmiot sporu między zwolennikami kompatybilizmu i libertarianizmu. Odmiennymi stanowiskami wobec problemu wolnej woli pozostają mocny determinizm i mocny inkompatybilizm. Oba stanowiska negują możliwość istnienia wolnej woli, podtrzymując jednocześnie tezę o istnieniu powszechnego determinizmu (mocny determinizm) lub ją negując (mocny inkompatybilizm). Warto nadmienić, że choć w generalnej klasyfikacji stanowisk wokół problemu istnienia wolnej woli i powszechności determinizmu wyróżniamy po dwa zbiory stanowisk broniących i negujących wolną wolę, to dla libertarian przyjęcie stanowiska kompatybilistycznego równałoby się z negacją wolnej woli (i na odwrót). Oba stanowiska broniące zasadności istnienia wolności prowadzą więc między sobą spór, którego przedmiot stanowić mogą: 1) definicja i zakres pojęć „wolność" i „wolna wola” (obie kategorie do dziś cechują się istotną dla ich istoty

4 Zob. T.A. Warfield, Kompatybilizm i inkompatybilizm: wybrane argumenty, „Roczniki Filozoficzne" 2006, nr 1, s. 217-239. Por. idem, Compatibilism and Incompatibilism: Some Arguments, [w:] M. Loux, D. Zimmerman, The Oxford Handbook of Metaphysics, Oxford 2005, s. 613-630.

5 Zob. J. Newman, op. cit., s. 360-368. 
nieokreślonością, co już na tym etapie może trwale uniemożliwiać zażegnanie sporu) oraz 2) definicja i zakres determinizmu. Ostatnia kategoria, a w szczególności jej liczne przejawy, również wymaga ponownego namysłu i współczesnego przedefiniowania problemu. Na tę potrzebę wskazuje przede wszystkim mnogość występujących $\mathrm{w}$ świecie determinacji (których rolę w procesie decyzyjnym coraz trudniej zasadnie pomijać lub argumentować za względnością ich oddziaływania) oraz dynamiczny rozwój nauk przyrodniczych, wprowadzających filozofię na nowe pole rozważań dotyczących determinizmu po naukowym „obaleniu” jego powszechności ${ }^{6}$ na rzecz indeterminizmu procesów subatomowych.

$\mathrm{Na}$ tle współczesnych odkryć nauk szczegółowych problem wolnej woli wciąż pozostaje nierozwiązaną kwestią klasycznej metafizyki, stale oddziałującą nie tylko na ontologie współczesnych badaczy problemu, ale w szczególności na szeroki obszar filozofii praktycznej, wymagający uzasadnienia tezy o istnieniu wolności podmiotu podejmującego działania. Czy wolność podmiotu może wyrażać się jednocześnie w niezdeterminowanych decyzjach podmiotu i determinacji działania? Tak intuicyjnie rozumiemy wolną wolę. Być może jednak determinizm może nie stać w konflikcie z zasadnością istnienia ludzkiej wolności, a nawet wspierać zasadność jej istnienia? Na te pytania starają się udzielić odpowiedzi nie tylko kompatybiliści, ale również Spinoza.

\section{SPINOZJAŃSKA IDEA WOLNOŚCI}

Jak wspomniałem wyżej, w zamyśle kompatybilistów nie każda koncepcja ludzkiej wolności musi z konieczności negować przyrodniczą określoność - jest wręcz przeciwnie, co wspiera stanowisko Spinozy. Jego definicja wolności brzmi bowiem następująco:

Co do mnie, nazywam wolną taką rzecz, która istnieje i działa wyłącznie na mocy konieczności swojej własnej natury, natomiast przymuszoną nazywam taką, która ze strony jakiejś innej podlega determinacji do istnienia i do działania w pewien określony sposób. [...] Widzisz zatem, że zasadzam wolność nie na swobodnym postanowieniu, ale na swobodnej konieczności ${ }^{7}$.

$6 \quad$ Używam wyrażenia ujętego w cudzysłowie ze względu na to, że determinizm u swych podstaw jest wciąż stanowiskiem metafizycznym, które może być wspierane (lub nie - jak w powyższym przypadku) przez rezultaty badań w ramach nauk przyrodniczych. Drugim powodem jest dyskusyjność relacji między procesami subatomowymi a zjawiskami w świecie makro, w którym zdroworozsądkowo i dla uniknięcia licznych paradoksów nie podważamy istnienia różnych form determinacji. Sprawa ta wymaga, rzecz jasna, o wiele głębszego namysłu.

7 B. Spinoza, List LVIII - Spinoza do Schullera [październik 1674], [w:] Listy mężów uczonych do Benedykta de Spinozy oraz odpowiedzi autora wielce pomocne dla wyjaśnienia jego dziet, Warszawa 1961, s. 261, cyt. za: P. Gut, Spinozjańska koncepcja wolności..., s. 55. 
Pobrane z czasopisma Annales I - Philosophy and Sociology http://philosophia.annales.umcs.pl Data: 26/04/2023 11:41:36

Filozofia wolności Barucha Spinozy w kontekście interpretacji kompatybilistycznej

Jak zauważa M.J. Kisner:

[...] definicja [ta] może wprawić w zdziwienie niektórych czytelników, ponieważ tak twierdzi [Spinoza], wolne działania wynikają z konieczności, co wyklucza powszechne przekonanie, że wolność wymaga braku determinacji przyczynowej bądź się w niej wyraża. Według wizji Spinozy to, czy nasze działania są determinowane przyczynowo, nie ma żadnego znaczenia wobec tego, czy jesteśmy wolni; [głosi on] innymi słowy, nasza wolność jest zgodna [a więc: kompatybilna - K.R.] $\mathrm{z}$ determinizmem przyczynowym ${ }^{8}$.

Niezależnie od tego, czy wolność woli uczynimy postulatem rozumu praktycznego (jak czynił to chociażby Kant) czy umiejscowimy ją nie pośród innych ludzkich atrybutów, a ujmować będziemy ją bezpośrednio jako podmiot (jak np. Sartre), wciąż możemy odnaleźć kompatybilistyczne ujęcia wolności. Głoszą one, że dopuszczenie istnienia choćby symbolicznej nieokreśloności w porządku przyczynowym w świecie nie tylko nie uzasadni wolności, ale także będzie stanowić argument przeciwko jej istnieniu. Losowość jako determinacja zewnętrzna będzie niwelować porządek przyczynowy, który jest wymagany, aby podmiot był zdolny do autodeterminacji działań, których chciałby być sprawcą. Przyczyna sprawcza działania znajduje się wtedy wewnątrz podmiotu, a nie na zewnątrz. Oba aspekty wolności (negatywny i pozytywny) nierozerwalnie i naprzemiennie łączą się ze sobą, wiążąc jednocześnie między sobą podmiot w szeregu antynomii wolności woli.

Jeżeli przyjąć tezę o istnieniu wolności nieposiadającej swojej zewnętrznej przyczyny, to w filozofii Spinozy wolny jest jedynie Bóg 9 . Nawet Bóg nie jest jednak wolny według klasycznego rozumienia liberum arbitrium voluntatis (a więc per accidens). Bóg stanowi przyczynę samą przez się, działa zaś z konieczności własnej boskiej natury ${ }^{10}$. Pojęcie wolnej woli natrafia na znaczne trudności przy zestawieniu jej z ideą Boga. Pozostając przy panteizmie Spinozy, Boga nie można pojmować jako decydenta na kształt ludzki ${ }^{11}$. Nie można też przyjąć, że mógłby

8 M.J. Kisner, op. cit., s. 18.

9 „Tylko Bóg jest przyczyną wolną. Bóg jeden bowiem istnieje wyłącznie z konieczności swojej natury [...] i wyłącznie z konieczności swojej natury działa [...]. A więc (na mocy def. 7) on jeden tylko jest przyczyną wolną" - B. Spinoza, Etyka w porządku geometrycznym dowiedziona, Warszawa 2008, cz. I, tw. 17, dodatek II, s. 29, cyt. za: P. Gut, Spinozjańska koncepcja wolności..., s. 57. Zob. J. Żuławski, Benedykt Spinoza, człowiek i dzieło/całość, Warszawa 1914, s. 63-64. Por. M.J. Kisner, op. cit., s. 19.

10 Zob. B. Spinoza, Etyka ..., cz. I, tw. 16, dodatek II i III, s. 28.

11 „Do natury Boga nie należy ani rozum, ani wola [...]. Otóż, jeśli rozum i wola mają należeć do wiecznej istoty Boga, to trzeba najwidoczniej przez każdy z tych atrybutów rozumieć coś innego niż to, co ludzie zwykli pospolicie rozumieć. Rozum bowiem i wola, które stanowić by miały istotę Boga, o całe niebo musiałyby się różnić od naszego rozumu i naszej woli i poza nazwą w niczym nie mogłyby być z nimi zgodne" - ibidem, cz. I, tw. 17, przypis, s. 30-31. 
On działać chociaż możliwie inaczej niż z konieczności dyktowanej przez własną naturę ${ }^{12}$.

Powyższa uwaga wskazuje, że nawet wolność Boga musi brać na swe barki konieczność własnej natury, nie jest więc nieokreśloną niczym swobodą decydowania na kształt ludzkiej wolnej woli. Dusza ludzka stanowi z kolei określony modus myślenia, przez co nie może być wolną przyczyną własnych działań ${ }^{13}$. Spinoza nie traktuje jednak braku indeterministycznej swobody jako równoznacznej z brakiem wolności. Przeciwieństwem wolności nie jest bowiem konieczność sama w sobie, a jedynie taki rodzaj przymusu - przemocy ${ }^{14}$, który wyklucza twórcze działanie człowieka. Na tę zależność w szczególności zwraca uwagę P. Gut. Stanowi ona pierwszy istotny element łączący myśl Spinozy z kompatybilizmem.

Filozofia Spinozy nie traktuje istnienia przyrodniczej (wręcz geometrycznej) konieczności jako warunku wystarczającego do wykluczenia istnienia nie tylko wolności Boga, ale przede wszystkim wolności człowieka. Szczególnie dziś można argumentować, że o wolności nie można mówić bez uznania istnienia przyczyn umożliwiających i warunkujących samo dokonywanie wyborów przez człowieka. Trudno byłoby mówić o wolnym decydowaniu bez uwzględniania jednocześnie roli procesu myślowego warunkującego podejmowanie decyzji. Ten z kolei przyczynowo powiązany jest m.in. z odpowiednią aktywnością funkcjonalną mózgu i nawet jeśli nie dokonujemy redukcji procesów mentalnych do procesów fizycznych, trudno mówić o realnej wolności decyzji wobec warunków niezbędnych do decydowania.

12 Teodyceę G.W. Leibniza, znakomicie uzupełniającą niniejszą problematykę i jednocześnie polemizującą z tezami Spinozy, pomijam ze względów objętościowych: „Spinoza utrzymuje, że wszystko powstało z pierwszej przyczyny lub pierwotnej natury za sprawą ślepej i całkowicie geometrycznej konieczności, przy czym ta pierwsza zasada rzeczy nie jest zdolna do wyboru, dobroci i rozumienia. Znalazłem, jak mi się wydaje, sposób, aby pokazać coś przeciwnego [...]. Dokonując bowiem nowych odkryć na temat natury działającej siły i praw ruchu, wykazałem, że nie podlegają one konieczności absolutnie geometrycznej, jak wydawał się sądzić Spinoza, i że nie są również zupełnie dowolne [...]. Zależą one [...] od stosownego wyboru, czyli od tego, co nazywam »zasadą najlepszego«. Dostrzegamy w tym, jak we wszystkich innych rzeczach, znamiona pierwszej substancji, której wytwory świadczą o najwyższej mądrości i składają się na najdoskonalszą z harmonii" - G.W. Leibniz, Teodycea. O dobroci Boga, wolności człowieka i pochodzeniu zła, Warszawa 2001, s. 32-33.

13 Zob. B. Spinoza, Etyka ..., cz. II, tw. 48, dowód, s. 128; P. Gut, Spinozjańska koncepcja wolności..., s. 58-59.

14 „Tajemnicą są dla mnie argumenty, za pomocą których silisz się mnie przekonać, że między przypadkowym i koniecznym nie zachodzi przeciwieństwo. [...] Twierdzenie, iż konieczność i wolność są to przeciwieństwa, wydaje się niemniej absurdalne i sprzeczne z rozumem. [...] Dlatego też sądzę, że nie odróżniasz w ogóle konieczności od przymusu czy też przemocy" - B. Spinoza, List LVI Spinoza do Boxela [październik 1674], [w:] Listy mężów uczonych ..., s. 252, cyt. za: P. Gut, Spinozjańska koncepcja wolności..., s. 59-60. 
Koncepcja Spinozy podąża jednak w swych wyjaśnieniach w odmiennym kierunku niż współczesna argumentacja (różnica powodowana jest rzecz jasna współczesną dostępnością do wiedzy na temat uwarunkowań neuronalnych). Spinoza nie dokonuje bezpośredniej redukcji umysłu do ciała, jego ontologia jest głęboko powiązana z jego własnym pojęciem substancji. Nie twierdzi też, że wolność stanowi wyłom z porządku konieczności ${ }^{15}$. Ontyczna jedność człowieka pozwala mu realizować własne działania, nie negując porządku przyrodniczego i konieczności, z jaką się on wiąże. Samo przekonanie Spinozy o takiej możliwości czyni jego koncepcję wolności podatną na celne ataki chociażby ze strony libertarian ${ }^{16}$, a zarazem jest głównym powodem do zestawiania jego koncepcji z założeniami kompatybilistów ${ }^{17}$.

\section{WOLNOŚĆ CZŁOWIEKA W OBLICZU KONIECZNOŚCI}

Powracając do kwestii odróżnienia przymusu od konieczności, pierwszą kategorię należy traktować u Spinozy jako zewnętrzną determinację wobec podmio$\mathrm{tu}^{18}$. Konieczność dyktowana przymusem przeczy wolności, ponieważ podmiot

15 „Wielu współczesnych autorów analizujących powyższy argument słusznie zauważa, że jego ważną przesłanką jest teza o ontycznej jedności tego, co umysłowe i tego, co cielesne, ponieważ tylko w ten sposób Spinoza mógł usprawiedliwić zastosowanie determinizmu przyczynowego do umysłu. Pomijając szczegóły, należy jednak podkreślić, że ontyczna jedność bytu ludzkiego nie oznacza na gruncie doktryny Spinozy redukcji warstwy umysłowej do cielesnej. Człowiek nie jest dla Spinozy rodzajem ciała materialnego. Umysł, którego wyznacznikiem jest myślenie, i ciało, którego wyznacznikiem jest rozciągłość, to odmienne atrybuty, niepodlegające żadnej wzajemnej determinacji. Wobec tego akceptacja zastosowania zasady przyczynowości do umysłu nie jest u Spinozy następstwem idei redukcji lub idei konstytuowania jednych warstw rzeczywistości przez inne. Wydaje się, że jest ona raczej konsekwencją ontycznej jedności bytu ludzkiego w połączeniu z twierdzeniem, wedle którego człowiek rozważany z punktu widzenia umysłu i ciała realizuje jeden i ten sam porządek" - P. Gut, Spinozjańska koncepcja wolności..., s. 59-60. Por. B. Spinoza, Etyka..., cz. II, tw. 7, s. 72.

16 Oddając sprawiedliwość zarzutom wymierzonym przeciwko kompatybilizmowi, inkompatybilista zasadnie postawi tu z pewnością pytanie, w jakiej mierze działanie podmiotu będzie własne.

17 Niezależnie od wyniku dalszych dociekań podjęty punkt wyjścia wykluczać będzie rozwiązanie Spinozy w perspektywie wielu badaczy jako adekwatne do dalszych rozważań. Mówiąc wprost, według stanowisk inkompatybilistycznych koncepcja Spinozy dyskwalifikuje możliwość istnienia wolności do tego stopnia, że szukanie jej nieindeterministycznej zasadności jej nonsensowne.

18 „Dwa najbardziej oczywiste fakty dotyczące Spinozy są zarazem najważniejsze dla zrozumienia zamiarów filozofa. Po pierwsze, jego kluczowe dzieło filozoficzne nie bez powodu nosi tytuł Etyka, i po drugie, jedynym wartościującym rozróżnieniem przyjętym ostatecznie w jego filozofii - nie licząc różnic między prawdą i fałszem oraz między adekwatnymi i nieadekwatnymi ideami - jest rozróżnienie między wolnością i poddaństwem. Właśnie w tych kategoriach, pierwszej 
poddany determinacji nie ma możliwości wpływu na łańcuch przyczynowo-skutkowy. Inaczej ma się sprawa z tzw. koniecznością swobodną, powiązaną ściśle z rozumną aktywnością podmiotu, według której to człowiek działa zgodnie z własną naturą. Drugi rodzaj konieczności jest powiązany z ludzkim poznaniem, wiedzą i determinacją, mającą swą przyczynę wewnątrz jednostki ${ }^{19}$. To właśnie w nim może się przejawiać zbieżność wolności z ujęciem kompatybilistycznym ${ }^{20}$, gdyż u jej podstaw zawarty jest determinizm, któremu podmiot jest w stanie się nie tyle przeciwstawiać, co kierować własnym działaniem za sprawą własnej natury mimo zewnętrznego przymusu.

Podsumowując, konieczność stanowi zagrożenie dla wolności jedynie wówczas, gdy podmiot jest wobec niej bezbronny, nie może kształtować własnego działania w odpowiedzi na narzucony przymus. Jeżeli mimo istnienia determinantu podmiot może kształtować własne działanie, wówczas konieczność stanowi jedynie ontologiczną podstawę uzasadniającą zdolność determinowania działań przez podmiot. Kwestia ta pozostaje trudnością zwłaszcza dla libertarian, którzy muszą wykazać, że: a) można uzasadnić istnienie negatywnej, indeterministycznej wolnej woli; b) wolność ta posiada również swój aspekt pozytywny, a więc mimo indeterminizmu u swych podstaw podmiot wciąż jest zdolny do determinowania działań. Jak podkreśla R. Kane, to właśnie ten drugi etap (zwany przez niego „górą inkompatybilizmu”21) stanowi zasadniczą trudność dla libertarian. Dla obrony stanowiska inkompatybilistycznego nie wystarczy tylko wykazać możliwość istnienia wolności mającej swoje źródło w nieokreśloności. Libertariański inkompatybilista musi przede wszystkim wykazać, że własność ta nie spowoduje w swym następstwie zerwania ciągłości między podejmowaną decyzją a działaniem, mającym być przez nią determinowanym. Zerwanie łańcucha przyczynowego celem wyłonienia w świecie wolności skutkuje trudnością uzasadnienia sprawstwa czynu podmiotu ze względu na możliwą (bo dopuszczoną) nieokreśloność - tym razem w procesie autodeterminacji. Podmiot musi posiadać możliwość autonomicznego kierowania nieokreśloną, libertariańską wolnością, aby można było przypisywać mu następnie sprawstwo działań na skutek decyzji, które w swoim przekonaniu podejmuje. Zdaniem Spinozy taka kontrola bazują-

pozytywnej i drugiej negatywnej, należy w ostatecznym rozrachunku oceniać człowieka, jego życie, działania i afekty. To za pomocą tych kategorii mędrzec ogląda i osądza swoje własne postępowanie, afekty i postawy, i to w świetle tego przeciwstawienia będzie on podejmować swoje decyzje, jeśli [rzeczywiście] jest mądry” - S. Hampshire, op. cit., s. 297, cyt. za: P. Gut, Spinozjańska koncepcja wolności..., s. 51.

19 Zob. P. Gut, Spinozjańska koncepcja wolności..., s. 54-55; B. Spinoza, List LVIII..., s. $260-265$.

20 Zob. M.J. Kisner, op. cit., s. 53.

${ }_{21}$ Zob. R. Kane, A Contemporary Introduction to Free Will, New York-Oxford 2005, s. 33-34. 
Pobrane z czasopisma Annales I - Philosophy and Sociology http://philosophia.annales.umcs.pl Data: 26/04/2023 11:41:36

Filozofia wolności Barucha Spinozy w kontekście interpretacji kompatybilistycznej

ca na przypadku czy wręcz losowości pozostaje niemożliwym do przyjęcia postulatem $^{22}$. Podobnie rzecz ma się z poszukiwaniem wolności poza porządkiem przyrodniczym.

Jeżeli wolność i konieczność (konieczność swobodna, a nie przymus) mają być ze sobą zgodne, to Spinozjańska idea wolności musi ograniczać samą siebie do wiedzy na temat funkcjonowania przyrody - przyczyn oraz skutków, jakie kierują człowiekiem. Dopiero taka wiedza, nabyta za sprawą poznania rzeczywistości, umożliwi podmiotowi działanie przemyślane, planujące, przewidujące i - co ważniejsze - wyprzedzające konieczność w jej stanowieniu. Działanie rozumne nie neguje więc konieczności przyrodniczej. Podmiot, rozumnie dopasowując się do jej uwarunkowań, pozostaje z nią nierozerwalnie złączony. Wiedza na temat przyczyn umożliwia mu zaś przewidywanie koniecznych skutków i dostosowanie swych działań w sposób bardziej wolny niż u osoby, która wiedzy na temat zjawisk jeszcze nie uzyskała. Wolność wybierania jest kompatybilna z koniecznością w tym zakresie, że nie popada w konflikt z oddziaływaniami przyczynowo-skutkowymi - jest w końcu ich rezultatem. Wiedza i działanie, ze względu na swoją rozumną naturę, dają jednak człowiekowi tę wolność, że za sprawą wiedzy jest w stanie dopasować swoje decyzje tak, by skutki działań potoczyły się zgodnie z jego oczekiwaniami.

Taką wolność można byłoby zilustrować na przykładzie dwóch żeglarzy znajdujących się w obliczu niebezpieczeństwa. Wykwalifikowanemu żeglarzowi (tzn. nie tylko wprawionemu w prowadzeniu jachtu za sprawą licznych doświadczeń, ale także posiadającemu zasób teoretycznej wiedzy zdobytej podczas szkoleń, niezbędnej dla uzyskania odpowiednich kwalifikacji) wystarczy sama obserwacja zachmurzenia nieba, by jasno i wyraźnie wskazać, czy dzisiejsze planowanie parogodzinnego wypłynięcia w rejs zakończy się sukcesem (oczywiście pod warunkiem niepojawienia się niespodziewanie czynników utrudniających podróż). Jeżeli zaś początkujący żeglarz uzależni podobny plan wypłynięcia jachtem wyłącznie od pobieżnej wiedzy na temat obserwacji pogody, prawdopodobnie popełni poważny błąd i narazi siebie i pozostałych członków wyprawy na niebezpieczeństwo. Takim ryzykiem jest np. pojawienie się szkwału, szczególnie niebezpiecznego dla niewielkich jachtów. Osoba niewykwalifikowana, nie posiadając jeszcze wiedzy np. na temat „wału szkwałowego” (łatwo zauważalnego z daleka i bezpośrednio poprzedzającego nawałnicę), może swoją niewiedzą bardzo ograniczyć sobie pole do działania, gdy dojdzie do gwałtownej burzy i bardzo silnego wiatru. Zarówno uczestnik rejsu nieposiadający jeszcze teoretycznej wie-

${ }^{22}$ Tezę tę rozwijam w końcowej części artykułu. Zob. P. Gut, Spinozjańska koncepcja wolności..., s. 56. 
Pobrane z czasopisma Annales I - Philosophy and Sociology http://philosophia.annales.umcs.pl Data: 26/04/2023 11:41:36

dzy na temat procesu kumulacji chmur, jak i wykwalifikowany żeglarz, przygotowany merytorycznie do wyruszenia w rejs, nie posiadają więc ani możliwości wpływu na kierunek wiatru, ani na jego siłę, ani rzecz jasna na samo pojawienie się burzy.

Powyższy przykład ma służyć refleksji, że to od wiedzy żeglarzy i ich decyzji zależeć będzie, czy trafnie zdołają przewidzieć nadchodzące niebezpieczeństwo oraz czy planowana przez nich podróż będzie bezpieczna. Posiadana przez wykwalifikowanego żeglarza wiedza zapewnia mu większą „wolność” podczas rejsu, ponieważ z większą pewnością będzie w stanie oszacować bezpieczeństwo wyprawy. Wiedza nie zapewnia mu jednak kontroli nad samymi zdarzeniami pogodowymi. Gdyby bowiem doszło już do takiego zjawiska jak szkwał, to nawet wykwalifikowanej załodze niezwykle trudno byłoby utrzymać stabilność łodzi.

\section{NAUKA O WOLI JAKO KROK W KIERUNKU KOMPATYBILIZMU}

Jak wspomniałem wyżej, trudno polemizować z zarzutami libertarian, którzy dążą do wykazania, że idea wolności w filozofii Spinozy niewiele ma wspólnego z wolnością woli. Jeśli wolność rozumiana jest inkompatybilistycznie (klasycznie, zgodnie z intuicyjnym ujęciem wolności), nie może się ona pojawiać w świecie mimo konieczności. Musi godzić w powszechność determinizmu, deklasując go, aby w następnej kolejności mierzyć się z koniecznością wykluczenia losowości zdarzeń w świecie - również (a być może jeszcze radykalniej) pozbawiających człowieka możliwości wolności.

Problem uzasadnienia wolności mimo powszechności determinizmu stanowi główną trudność dla kompatybilistów. Jeśli koncepcję Spinozy będziemy traktować jako przejaw kompatybilizmu, to jego ujęcie wolności będzie w znacznej mierze bliższe działaniu rozumnemu i powiązanym z nim zagadnieniom: racjonalnego nakierowywania woli, wiedzy na temat rzeczywistości oraz kierujących nią determinant oraz determinacyjnej mocy ${ }^{23}$ duszy, umożliwiającej wprowadzanie w świat determinacji za sprawą woli. Jak wspomina L. Meijer, wola nakierowana w sposób wolny łączy się problemowo ze związkiem psychofizycznym (wystę-

${ }^{23}$ „Moc duszy określona jest wyłącznie przez wiedzę, niemoc zaś, czyli stan bierny, oceniany jest jedynie przez brak wiedzy" - B. Spinoza, Etyka ..., cz. V, tw. 20, przypis, s. 354. W kontekście mocy wolnością także wyraża się u Spinozy umiłowanie Boga w jego relacji wobec modi. Taka interpretacja wolności miałaby prowadzić człowieka do szczęśliwości. Newman wskazuje jednak również, że na Spinozjańskie operowanie terminem „Boga” zamiast ,jedynej substancji” mogły mieć wpływ polityczne oraz społeczne naciski, skłaniając Spinozę do tworzenia pozoru ortodoksji jego koncepcji dla jej korzystniejszego późniejszego odbioru. Podobne stanowisko na temat Spinozjańskiej idei wolności prezentuje Kisner. Zob. P. Gut, Spinoza o naturze ludzkiej, Lublin 2011, s. 225; J. Newman, op. cit., s. 367-368; M.J. Kisner, op. cit., s. 55-56. 
pującym chociażby w Kartezjańskim dualizmie) ${ }^{24}$. W monizmie Spinozy jednak dusza ludzka spotyka się z ograniczeniami mającymi wpływ na jej oddziaływanie. Ograniczenia te wynikają m.in. z (tu w duchu Kartezjańskiego sceptycyzmu metodycznego) niedoskonałości ludzkiej introspekcji we własne procesy mentalne ${ }^{25}$. Ograniczenia ludzkiego umysłu w kwestii wyprowadzania sądów można natomiast rozumieć dwojako. Po pierwsze, każdorazowo podejmując decyzję, nie odczuwamy złożoności procesów, które umożliwiają nam podejmowanie decyzji. Nawet jeśli dysponujemy teoretyczną wiedzą na temat uwarunkowań neuronalnych, to wciąż posiadamy jednostkową jaźń oraz poczucie, że to my mamy wpływ na działania, które bezpośrednio nas dotyczą ${ }^{26}$. Po drugie (pozostając bliżej Spinozy), na treść naszych sądów mają wpływ idee, które kształtują tory naszego rozumowania ze względu na wewnętrzną koherencję twierdzeń ujmujących istotę danej idei ${ }^{27}$. Taka wewnętrzna koherencja występuje chociażby w przypadku

24, „...] Kartezjusz, jak widać z czwartej części Rozprawy, z drugiej Medytacji i z innych miejsc, przyjmuje po prostu bez dowodu, że dusza ludzka jest substancją myślącą w sensie bezwzględnym. Autor nasz [Spinoza - K.R.] natomiast zgadza się wprawdzie co do tego, że istnieje w naturze substancja myśląca, przeczy atoli temu, by stanowiła ona istotę duszy ludzkiej. Twierdzi przeciwnie, że myślenie, podobnie jak rozciągłość, niczym nie jest ograniczone; podobnie też jak ciało ludzkie jest rozciągłością nie w sensie bezwzględnym, lecz tylko rozciągłością w określony sposób ograniczoną przez ruch i spoczynek na mocy praw natury rozciągłej, tak i dusza ludzka czy też duch jest myśleniem nie w sensie bezwzględnym, ale tylko w określony sposób ograniczonym przez idee stosownie do praw natury myślącej; myślenie to, jak wnioskuje, z koniecznością istnieje, skoro tylko istnieć zaczyna ciało ludzkie" - L. Meijer, Do życzliwego czytelnika (Zasady filozofii Kartezjusza w porządku geometrycznym wywiedzione), [w:] B. Spinoza, Pisma wczesne, Warszawa 1969, s. 9-10, cyt. za: P. Gut, Spinozjańska koncepcja wolności..., s. 52-53.

25 „Otóż i owa wolność ludzka, której posiadaniem wszyscy się chełpią, a która na tym tylko polega, że ludzie świadomi są swoich popędów, nieświadomi natomiast przyczyn, których determinacji podlegają. Tak to dziecko jest przekonane, że swobodnie pragnie mleka, rozzłoszczony chłopiec - że chce się zemścić, tchórzliwy - że chce uciekać. Podobnie myśli pijany, że na mocy swobodnego postanowienia mówi coś, co później, na trzeźwo, wolałby, iżby nie zostało powiedziane. Tak samo obłąkany, gaduła i mnóstwo innych ludzi tego gatunku wyobraża sobie, iż postępuje na mocy swobodnego postępowania umysłowego, nie zaś - że bodźce zewnętrzne wprawiają ich w ruch. I niełatwo się ludziom wyzwolić od tego przesądu, jako że wszystkim jest on wrodzony" - B. Spinoza, List LVIII..., s. 262, cyt. za: P. Gut, Spinozjańska koncepcja wolności..., s. 60. Por. J. Newman, op. cit., s. 365-366.

26 Namysł nad tą kwestią pozostaje niezmiennie zagadnieniem powiązanym nie tylko z procesem psychofizycznym, ale w szczególności z wolną wolą. Trudność tematu ukazują chociażby N. Murphy i W.S. Brown w książce Did My Neurons Make Me Do It?, w której rozpatrują problematykę przyczynowości i wolności woli w kontekście wybranych koncepcji filozoficznych (także dualizmu Kartezjańskiego), nauk kognitywnych oraz takich zagadnień, jak emergencja czy sprzężenie zwrotne - zagadnień, które ze względów objętościowych pracy pomijam. Zob. N. Murphy, W.S. Brown, Did My Neurons Make Me Do It?: Philosophical and Neurobiological Perspectives on Moral Responsibility and Free Will, Oxford 2007. Por. P. Gut, Spinoza o naturze..., s. 183-189.

27 Jako przykład powyższej zależności Spinoza ukazuje obustronną relację pomiędzy ideą trójkąta i nierozerwalnie zawartymi w niej poszczególnymi twierdzeniami, współtworzącymi jej 
twierdzeń dotyczących zależności figur geometrycznych. Zależność ta z drugiej strony pozostawia do dziś nierozwiązanymi niektóre problemy matematyczno-filozoficzne, jak np. trysekcja kąta, kwadratura koła czy podwojenie sześcianu.

Zaprezentowane powyżej ograniczenia umysłu nie spotykają się z krytyką ze strony Spinozy na rzecz wolności. Jak sam podaje, ,wola i rozum są tym samym”28, co wiąże się ściśle ze wspomnianym już dowodem na twierdzenie 48, traktujące ludzką duszę jako określony modus myślenia ${ }^{29}$. Dusza ludzka z konieczności swej rozumnej natury nie może być niczym niezdeterminowaną (tj. wolną) przyczyną własnych działań: ,[...] musi determinować ją (na mocy tw. 28 cz. I) przyczyna, którą także determinuje inna, a tę z kolei inna itd." ${ }^{30}$. Spinoza utożsamia jednak wolność ludzką z wiedzą, obie zaś - z władzą duszy ${ }^{31}$. Przedefiniowuje przez to wolność tak, aby odmiennie traktowana od idei wolnej woli mogła być uzgodniona z koniecznością wewnętrzną, nieprzeczącą zewnętrznym uwarunkowaniom ${ }^{32}$. Spinoza opisuje taki kompatybilizm jako naukę o woli, przeciwstawiając go krytykowanej nauce o wolnej woli (liberum arbitrium) ${ }^{33}$. Taka idea wolności pozwala na postawienie takich samych zarzutów Spinozie, jak kompatybilistom. Wedle tych zarzutów niemożliwa jest wolność pogodzona z koniecznością. Równie aporetyczne są próby przedefiniowywania wolności przez Spinozę oraz kompatybilistów. Osadzanie wolności bardziej w kontroli motywów za sprawą woli niż w metafizycznej dyspozycji podmiotu do działania nieokreślonego pozostawia duże wątpliwości co do kwestii, czy wciąż można mówić o wolności ${ }^{34}$. Spinozjańska

istotę. Zob. B. Spinoza, Etyka ..., cz. II, tw. 49, dowód, s. 130; P. Gut, Spinozjańska koncepcja wolności..., s. 61-63.

28 B. Spinoza, Etyka ..., cz. II, tw. 49, dodatek, s. 130. Zob. ibidem, przypis, s. 130-139.

29 Pozostaje przy tym na mocy zarzut wspierający się przykładem osła Burridana, który Spinoza omawia w Etyce. W przykładzie rzeczony głodny i spragniony osioł znajduje się dokładnie między wiadrem wody a stogiem siana. Ostatecznie zwierzę musi paść na skutek niezdecydowania, ponieważ determinanty są wyrównane, zwierzę zaś nie posiada wolnej woli. Spinoza zgadza się z taką konsekwencją wyrównanych determinant. Zob. ibidem, przypis, s. 134 i 137-138.

30 Ibidem, cz. II, tw. 48, dowód, s. 128.

31 Zob. ibidem, cz. V, „O mocy rozumu, czyli o wolności ludzkiej” - przedmowa, s. 334.

32 M.J. Kisner, op. cit., s. 56-60.

33 „Otóż ci, którzy mniemają, że idee polegają na obrazach, wytwarzających się w nas wskutek zetknięcia się z ciałami, wmawiają w siebie, że takie idee rzeczy, dla których nie możemy wytworzyć żadnego podobnego obrazu, nie są ideami, lecz tylko urojeniami, które zmyślamy z wolnego wyboru woli (ex libero voluntaris arbitro)" - B. Spinoza, Etyka ..., cz. II, tw. 49, przypis, s. 132.

34 Jako przykład trudności może służyć zasadność przypisywania moralnej odpowiedzialności w przypadku poczucia wolności, któremu towarzyszy jednak zewnętrzna interwencja, nieświadoma z perspektywy podmiotu. Kwestię tę opisuję szerzej podczas analizy stanowiska semikompatybilistycznego w kontekście Frankfurtowskiej zasady alternatywnych możliwości. Zob. H.G. Frankfurt, Alternatywne możliwości i odpowiedzialność moralna, [w:] J. Hołówka (red.), Filozofia moralności. Postanowienie i odpowiedzialność moralna, Warszawa 1997, s. 163-174. Por. idem, Alternate 
Pobrane z czasopisma Annales I - Philosophy and Sociology http://philosophia.annales.umcs.pl Data: 26/04/2023 11:41:36

Filozofia wolności Barucha Spinozy w kontekście interpretacji kompatybilistycznej

idea wolności (podobnie do wolnościowych założeń kompatybilistów ${ }^{35}$ ) przeciwstawia się wreszcie bardziej przymusowi niż obiektywnej konieczności; w procesie decyzyjnym dostrzegany jest również prymat woli nad wolnością oraz intencji nad determinacjami - ponownie wbrew argumentom libertarian ${ }^{36}$.

Warto na tym etapie wspomnieć o sceptycznym stanowisku Newmana w kwestii przypisywania kompatybilizmu Spinozie. Jego zdaniem, aby Spinozę można było uznawać za kompatybilistę, powinien on jasno rozróżniać przyczynę zewnętrzną pod postacią związku przyczynowego od przyczyny mającej swój początek w ludzkim rozumie. Ontologia Spinozy wykracza według Newmana poza argumentację kompatybilistów, którzy koncentrując się na występowaniu związku przyczynowego wyłącznie między konkretnymi zdarzeniami, pozostawiają dociekania nad causa sui jako nieistotne dla przypisywania moralnej odpowiedzialności za czyn ${ }^{37}$. Argument Newmana ma źródło w Spinozjańskiej koncepcji substancji, a w szczególności w tezie, że rozciągłość oraz myślenie stanowią atrybuty jednej substancji ${ }^{38}$. Ciało i dusza łączą się w jednostce ludzkiej, podczas gdy kompatybilistyczne nakierowanie woli szukałoby rozwiązania bardziej dualistycznego, aby wykazać niewspółmierność determinacji przyrodniczej i rozumowej, omijając tym samym zarzut wykluczania wolności przez determinizm. Z tym argumentem zgadzam się jedynie częściowo. Spinoza nie dąży do dualistycznego uzasadnienia wolności, przez co zmuszony jest do argumentacji za wolnością opartą na wiedzy o przyczynach i ich skutkach. Autodeterminacja podmiotu natrafia jednak na zasadniczą trudność w momencie próby uzasadnienia jej jakościowej odmienności od uwarunkowania przyrodniczego. Newman dostrzega trudność rozwiązania Spinozy w nieokreślonej relacji związku przyczynowo-skutkowego z autodeterminacją opartą na wiedzy o przyczynach i skutkach. Wątpliwość ta nie będzie kreowała Spinozy jako libertarianina, lecz jako mocnego (tj. inkompatybilistycznego) deterministę. Newman w swojej interpretacji

\footnotetext{
Possibilities and Moral Responsibility, "Journal of Philosophy" 1969, Vol. 66(23), DOI: https://doi. org/10.2307/2023833, s. 829-839; J. Newman, op. cit., 362; K. Rojek, Kontrfaktyczna interwencja jako teoretyczne i praktyczne zagrożenie dla wolności. Krytyczna analiza Frankfurt Cases, „Kultura i Wartości” 2015, nr 4 (16), http://dx.doi.org/10.17951/kw.2015.16.23, s. 23-48; idem, Semikompatybilizm J.M. Fischera w kontekście alternatywnych możliwości działań, „Idea. Studia nad Strukturą i Rozwojem Pojęć Filozoficznych" 2015, nr 27, DOI: https://doi.org/10.15290/idea.2015.27.10, s. $177-198$.

35 Zob. T.A. Warfield, Kompatybilizm i inkompatybilizm..., s. 223-224. Por. K. Rojek, Semikompatybilizm..., s. 194.

${ }^{36}$ Zob. J. Newman, op. cit., s. 362.

37 Zob. ibidem, s. 363.

38 Zob. Ł. Siciński, Koncepcja substancji u Spinozy, www.racjonalista.pl/kk.php/t,5316 [dostęp: 20.02.2018].
} 
nie dostrzega ujednolicenia wolności z wiedzą, stale poddając tę pierwszą libertariańskim kryteriom. Zarzut jest oczywiście słuszny, lecz w mojej opinii Spinoza mógłby (podobnie jak rozumie on determinację za sprawą natury) nie uważać go jako przeczącego wolności woli, tę bowiem odrzucił już we wstępnych rozważaniach nauki o woli, uznając ją za co najwyżej iluzoryczną ${ }^{39}$. Takie stanowisko zdaje się wspierać interpretacja Guta:

Zasadnicza różnica zachodzi jednak między Spinozą a zwolennikami stanowiska nazywanego obecnie libertariańskim. Według tego stanowiska pojęcie wolności, określanej jako działanie zgodne z własną naturą, bez żadnego zdeterminowania zewnętrznego (przymusu), nie oddaje pełnej treści pojęcia „wolność”. Stąd samo rozróżnienie na przyczyny wewnętrzne i zewnętrzne nie jest wystarczające. Przyczynowość od wewnątrz może bowiem tak samo eliminować wolność jak przyczynowość z zewnątrz. Prawdziwa wolność musi polegać na podejmowaniu działań, za którymi nie ma żadnych przyczyn. Jedynie pod tym warunkiem podmiot realnie rozporządza możliwością alternatywnego działania, przyjąwszy nawet, że wszystkie przyczyny pozostają te same. Tam, gdzie nie pojawia się żadna możliwość takiego wyboru - uważają libertarianie - nie ma również wolności. Spinoza natomiast utrzymywał, że wolność w tej postaci jest po prostu niemożliwa, ponieważ implikuje przypadkowość. Przypadkowość tymczasem, rozumiana jako sytuacja niemająca żadnej przyczyny, jest w istocie fikcją, która nie może być użyta na określenie czegokolwiek realnego również wolności. Chcąc uniknąć przypadkowości, należy więc uznać, że prawdziwa wolność nie polega wcale na wyborze tego lub tamtego działania, lecz na działaniu zgodnym z własną naturą, czyli przez przyczyny wewnętrzne. Jedynie w tym sensie wolność jest czymś realnym ${ }^{40}$.

Zdaniem Newmana rozważania Spinozy wykraczają poza współczesny kompatybilizm również z innego powodu. Koncepcja substancji Spinozy może stanowić podstawę dla współczesnego namysłu nad przyczynowaniem mentalnym, ściśle związanym z obserwacją procesów w mózgu, a nie analizy pojęcia rozu$\mathrm{mu}^{41}$. Monistyczna ontologia Spinozy jako swoją podstawę uznaje Boga tożsamego z przyrodą, materią, stwarzającą Naturą. Spinozjańska koncepcja myślenia zakorzenionego w panteistycznej metafizyce nie pozwala przez to uznać jego koncepcji wolności za kompatybilizm ${ }^{42}$.

\section{UWAGI KOŃCOWE}

Zasadniczą trudnością pozostaje ustalenie terminologicznej granicy Spinozjańskiej idei wolności oraz ukazanie jej relacji do kategorii wolnej woli. Sprawą bezdyskusyjną pozostaje określenie relacji Spinozjańskiej wolności do idei libe-

39 Por. P. Gut, Spinozjańska koncepcja wolności..., s. 56.

40 Ibidem.

41 Zob. J. Newman, op. cit., s. 364-365.

42 Zob. ibidem, s. 363-367. 
Pobrane z czasopisma Annales I - Philosophy and Sociology http://philosophia.annales.umcs.pl Data: 26/04/2023 11:41:36

Filozofia wolności Barucha Spinozy w kontekście interpretacji kompatybilistycznej

rum arbitrium. Czytając Etykę, nietrudno wskazać na wykluczające się Spinozjańskie rozumienie wolności z klasycznym rozumieniem wolnej woli (pomijając otwartą krytykę takowej). Jeśli utożsamienie wolności z wiedzą na temat zjawisk pozbawia ją możliwości rozpatrywania jej jako wolnej, pozostaje ona wówczas sprzeczna zarówno z ideą libertarianizmu, jak i kompatybilizmu. Ponieważ przedstawiciele kompatybilizmu nie zgadzają się z libertariańskim ujęciem liberum arbitrium i dążą do wykazywania możliwości wolności mimo określoności zdarzeń, stanowisko Spinozy na tym etapie można uznać za kompatybilistyczne. Będzie to jedynie element kompatybilistyczny, ponieważ - jak wskazuje Newman - metafizyczne wyjaśnienie relacji między działaniem rozumnym i przyczynowo zdeterminowanym światem wykracza już poza argumenty kompatybilizmu, starającego się unikać metafizycznego uzasadniania wolności. Problem definicji wolności dotyczy nie tyle przypadku Spinozy, co zasadności kompatybilizmu jako stanowiska filozoficznego i tego, czy może ono zasadnie dopuszczać istnienie wolnej woli innej niż jej ujęcie inkompatybilistyczne.

Jak starałem się dowieść, Spinozjańska koncepcja wolności klasyfikuje się wciąż pośród stanowisk traktujących o wolności jednostki w stosunku do przyrody. Rozważania w pracy ukazały szereg trudności łączących rozwiązania Spinozy i kompatybilistów. Analiza rozbieżnych interpretacji myśli Spinozy wskazała, że nie sposób wykazać bezsprzecznej koherencji między jego filozofią wolności a argumentacją słabego determinizmu - nie taki był jednak cel artykułu. Choć ukazanie aktualności myśli Spinozy bazującej na bezwzględnym determinizmie może wydawać się dyskusyjne z perspektywy obecnego naukowego obrazu świata (dopuszczającego wszak zjawiska indeterministyczne), dyskusyjność ta nie przeczy zasadności argumentacji Spinozy, a jedynie godzi w deterministyczny kształt jego ontologii. Ponieważ współczesny słaby determinizm (mimo licznej krytyki) traktowany jest powszechnie jako filozoficzne stanowisko za istnieniem wolności mimo powszechności determinizmu (chociażby w postaci statystycznej), powiązanie kompatybilizmu ze Spinozjańską wolnością wydaje mi się wciąż zasadne, a z pewnością warte dalszego namysłu.

\section{BIBLIOGRAFIA}

Gut P., Spinoza o naturze ludzkiej, Lublin 2011.

Gut P., Spinozjańska koncepcja wolności jako działania rozumnego, zgodnego z natura i cnotliwego, „Roczniki Filozoficzne” 2010, nr 1.

Frankfurt H.G., Alternate Possibilities and Moral Responsibility, "Journal of Philosophy” 1969, Vol. 66(23), DOI: https://doi.org/10.2307/2023833.

Frankfurt H.G., Alternatywne możliwości i odpowiedzialność moralna, [w:] J. Hołówka (red.), Filozofia moralności. Postanowienie i odpowiedzialność moralna, Warszawa 1997. 
Hampshire S., Spinoza and the Idea of Freedom, [w:] M. Grene (ed.), Spinoza: A Collection of Critical Essays, New York 1973.

Kane R., A Contemporary Introduction to Free Will, New York-Oxford 2005.

Kisner M.J., Spinoza on Human Freedom. Reason, Autonomy and the Good Life, Cambridge 2011.

Leibniz G.W., Teodycea. O dobroci Boga, wolności człowieka i pochodzeniu zła, Warszawa 2001.

Meijer L., Do życzliwego czytelnika (Zasady filozofii Kartezjusza w porzadku geometrycznym wywiedzione), [w:] B. Spinoza, Pisma wczesne, Warszawa 1969.

Murphy N., Brown W.S., Did My Neurons Make Me Do It?: Philosophical and Neurobiological Perspectives on Moral Responsibility and Free Will, Oxford 2007.

Newman J., The Compatibilist Interpretation of Spinoza, "The Personalist” 1974, Vol. 55(4).

Rojek K., Kontrfaktyczna interwencja jako teoretyczne i praktyczne zagrożenie dla wolności. Krytyczna analiza Frankfurt Cases, „Kultura i Wartości” 2015, nr 4, DOI: http://dx.doi.org/10.17951/kw.2015.16.23.

Rojek K., Semikompatybilizm J.M. Fischera $w$ kontekście alternatywnych możliwości działań, „Idea. Studia nad Strukturą i Rozwojem Pojęć Filozoficznych” 2015, nr 27,

DOI: https://doi.org/10.15290/idea.2015.27.10.

Siciński Ł., Koncepcja substancji u Spinozy, www.racjonalista.pl/kk.php/t,5316 [dostęp: 20.02.2018].

Spinoza B., Etyka w porządku geometrycznym dowiedziona, Warszawa 2008.

Spinoza B., List LVI Spinoza do Boxela [październik 1674], [w:] Listy mężów uczonych do Benedykta de Spinozy oraz odpowiedzi autora wielce pomocne dla wyjaśnienia jego dziet, Warszawa 1961.

Spinoza B., List LVIII - Spinoza do Schullera [październik 1674], [w:] Listy mężów uczonych do Benedykta de Spinozy oraz odpowiedzi autora wielce pomocne dla wyjaśnienia jego dziet, Warszawa 1961.

Warfield T.A., Compatibilism and Incompatibilism: Some Arguments, [w:] M. Loux, D. Zimmerman, The Oxford Handbook of Metaphysics, Oxford 2005.

Warfield T.A., Kompatybilizm i inkompatybilizm: wybrane argumenty, „Roczniki Filozoficzne” 2006, nr 1.

Żuławski J., Benedykt Spinoza, człowiek i dzieło/całość, Warszawa 1914.

\section{SUMMARY}

The article attempts to show the relationship of the philosophical idea of freedom in the philosophy of Baruch Spinoza in the context of the currently developed idea of compatibilism and selected arguments used by compatibilists and libertarian understanding of free will. The purpose of the article was to show the possibility of interpretation of Spinoza's philosophy of freedom from the perspective of compatibilism and to indicate the reasons, why such a comparison will remain debatable. The problem analysis presented in the text is also supposed to prompt us to consider, whether in the ongoing renaissance involving the problem of the existence of free will in the context of determinism there is still place for classical attempts to solve the problem, which undoubtedly is the pantheistic philosophy of Spinoza.

Keywords: Spinoza; freedom; compatibilism; pantheism; free will 
Pobrane z czasopisma Annales I - Philosophy and Sociology http://philosophia.annales.umcs.pl Data: 26/04/2023 11:41:36

Filozofia wolności Barucha Spinozy w kontekście interpretacji kompatybilistycznej 71

\section{STRESZCZENIE}

W artykule podjęto próbę ukazania filozoficznych zależności idei wolności w filozofii Barucha Spinozy w kontekście współcześnie rozwijanej idei kompatybilizmu i wybranych argumentów stosowanych przez kompatybilistów oraz libertariańskiego rozumienia wolnej woli. Celem było ukazanie możliwości interpretacji filozofii wolności Spinozy z perspektywy kompatybilizmu oraz wskazanie powodów, dla których takie porównanie jest dyskusyjne. Przedstawiona w opracowaniu analiza problemowa ma również skłaniać do podjęcia namysłu nad tym, czy w trwającym renesansie obejmującym problem istnienia wolnej woli w kontekście determinizmu można odnaleźć miejsce dla klasycznych prób rozwiązań problemu, jakie niewątpliwie stanowi panteistyczna filozofia Spinozy.

Słowa kluczowe: Spinoza; wolność; kompatybilizm; panteizm; wolna wola 